\title{
PROFIL PEMERIKSAAN PADA SEDIMEN URIN PASIEN INFEKSI SALURAN KEMIH MENGGUNAKAN ALAT DIRUI FUS-100
}

\author{
Profile Of Examination On Urine Sediment Of Urinary Tract Infection Patients Using \\ Dirui FUS-100 \\ ${ }^{1}$ Zulfikar Ali Hasan, ${ }^{2}$ Rafika \\ ${ }^{1,2}$ Jurusan Analis Kesehatan, Poltekkes Kemenkes Makassar \\ Koresponden : fikaroxy@gmail.com
}

\begin{abstract}
Urine sediment examination aims to detect and identify insoluble materials in urine. Blood, kidneys, lower genitourinary tract and external contamination can trigger the appearance of sediment in urine such as leukocytes, erythrocytes, epithelial cells, cylinders, bacteria, and other non-organic crystals. The purpose of this study was to determine the profile of urine sediment examination using Dirui Fus-100 device in kemi tract infection patients. descriptive design. The research was conducted at Dr Wahidin Sudirohusodo Hospital in 2020. The sample of this study was suspek patients whose clinical symptoms and medical records as many as 30 people were taken consequtive sampling of 30 people suspek UTIs. Examination material in the form of urine sediment using Dirui Urine Analyzer FUS-100. The results of this study showed that from 30 urine samples from urinary tract infection patients obtained the number of erythrocyte cells has a maximum value of 189 HPF almost all samples increased from normal values. The leukocyte cell value detected also showed a high value of 254 HPF from the normal value. Similarly, the number of bacterial cells found in the examination of this tool has the highest value of 12 HPF. Obtained the number of urine erythrocytes $>3$ HLP as many as 20 people (67\%). While the number of urine erythrocytes 0 - 3 HLP is found in 10 people (33\%). Leukocytes as many as 20 people (67\%) has a urine erythrocyte count of $>4$ HLP. While patients with the number of urine leukocytes 0-4 HLP is found in 10 people (33\%). Patients had urine bacteria as many as 24 people (80\%) has a urine bacteria count of 0 1 HLP. While patients with the amount of urine bacteria $>1$ HLP found in 6 people (20\%). Keywords : Urine Sediment Examination, Urinary Tract Infection
\end{abstract}

\begin{abstract}
ABSTRAK
Pemeriksaan sedimen urine bertujuan untuk mendeteksi dan identifikasi bahan yang tak larut dalam urine. Darah, ginjal, saluran genitourinaria bawah dan kontaminasi eksternal dapat memicu munculnya sedimen dalam urine seperti leukosit, eritrosit, sel epitel, silinder, bakteri, dan kristal non organik lainnya. Tujuan penelitian ini mengetahui profil pemeriksaan sedimen urin menggunakan alat Dirui Fus-100 pada pasien infeksi saluran kemih. Penelitian dilaksanakan di RSUP Dr Wahidin Sudirohusodo tahun 2020. Sampel penelitian ini adalah pasien suspek yang gejala klinis dan catatan medis sebanyak 30 orang yang diambil secara consequtive sampling suspek ISK. Bahan pemeriksaan berupa sedimen urine menggunakan Dirui Urin Analyzer Fus-100. Hasil penelitian ini menunjukkan bahwa dari 30 sampel urin dari pasien infeksi saluran kemih didapatkan jumlah sel eritrosit memiliki nilai maksimun 189 HPF hampir semua sampel mengalami
\end{abstract}


peningkatan dari nilai normal. Nilai sel leukosit yang terdeteksi juga menunjukkan nilai tinggi 254 HPF dari nilai normal. Begitu juga jumlah sel bakteri yang ditemukan dalam pemeriksaan alat ini memiliki nilai tertinggi $12 \mathrm{HPF}$. Diperoleh jumlah eritrosit urine $>3$ HLP sebanyak 20 orang (67\%). Sedangkan jumlah eritrosit urine 0- 3 HLP terdapat pada 10 orang (33\%). Leukosituria sebanyak 20 orang (67\%) memiliki jumlah eritrosit urine $>4$ HLP. Sedangkan pasien dengan jumlah leukosit urine 0- 4 HLP terdapat pada 10 orang (33\%). Pasien memiliki bakteri urine sebanyak 24 orang (80\%) memiliki jumlah bakteri urine 0 - 1 HLP. Sedangkan pasien dengan jumlah bakteri urine $>1$ HLP terdapat pada 6 orang (20\%).

Kata Kunci : Pemeriksaan Sedimen Urin, Infeksi Saluran Kemih

\section{PENDAHULUAN}

Infeksi saluran kemih (ISK) adalah penyakit infeksi yang kedua tersering pada tubuh sesudah infeksi saluran pernafasan dan sebanyak 8,3 juta kasus dilaporkan per tahun. Infeksi ini juga lebih sering dijumpai pada wanita dari pada laki-laki. Infeksi saluran kemih di Indonesia dan prevalensinya masih cukup tinggi. Walaupun kesakitan dan kematian dari infeksi saluran kemih berkaitan dengan kateter di anggap relatif rendah di bandingkan infeksi nosokomial lainnya (Kausuhe, J., Pangemanan and Onibala, 2017).

Menurut Survei Perawatan Medis Ambulatory National Hospital, infeksi saluran kemih terjadi sekitar 1 juta kunjungan di gawat darurat, mengakibatkan 100.000 orang dirawat di rumah sakit (Foxman, 2002).

Mikroorganisme penyebab ISK terbanyak adalah Escherichia coli yang ditemukan sekitar 70\%-95\% kasus dan Staphylococcus saprophyticus sekitar $5 \%-10 \%$ kasus . Berdasarkan pengalaman pada hari ke-7, ada sekitar $15 \%$ sampai $20 \%$ perbedaan respon klinis infeksi saluran kemih yang memerlukan rawat inap yang disebabkan oleh Escherichia coli (Bartoletti et al., 2016).

Pemeriksaan mikroskopis atau pemeriksaan sedimen urine bertujuan untuk mendeteksi dan identifikasi bahan yang tak larut dalam urine. Darah, ginjal, saluran genitourinaria bawah dan kontaminasi eksternal dapat memicu munculnya sedimen dalam urine seperti leukosit, eritrosit, sel epitel, silinder, bakteri, dan kristal non organik lainnya. Pemeriksaan sedimen urine meliputi identifikasi dan kuantisasi dari sedimen tersebut.(Strasinger and dan Di Lorenzo, 2016). Pemeriksaan mikroskopis urine memberikan manfaat untuk mendeteksi kelainan ginjal dan saluran kemih serta memantau hasil pengobatan (Brunzel, 2013).

Urine yang dipakai untuk pemeriksaan sedimen sebaiknya adalah urine segar atau urine yang dikumpulkan dengan pengawet, sebaiknya formalin. Pemeriksaan sedimen urine konvensional dilakukan dengan mengendapkan unsur sedimen menggunakan sentrifus. Endapan kemudian diletakkan diatas kaca objek dan ditutup dengan kaca penutup (Hardjoeno and Fitriani., no date). Pemeriksaan sedimen urine secara manual yaitu dengan mikroskop telah menjadi baku emas dalam pemeriksaan sedimen urine di laboratorium selama beberapa decade (Cameron, 2015).

Seiring dengan perkembangan teknologi, pemeriksaan urinalisis Makroskopik dan Mikroskopik Urine sudah dapat dilalukan secara otomatis dengan menggunakan Urin Analyzer. Salah satu alat urin analyzer yang telah dipake di Indonesia adalah Dirui Urin Analyzer H800 untuk pemeriksaan 
Makroskopik dan Kimia Urine, dan FUS 100 untuk pemeriksaan sedimen Urine. Alat ini dapat melakukan pemeriksaan secara terpisah atau bersamaan antara Pemeriksaan Makroskopi , Kimia dan Pemeriksaan Mikroskopik.

Pemeriksaan secara manual masih menjadi baku emas dalam pemeriksaan mikroskopik atau sedimen urine. Namun dalam pemeriksaan sedimen urine secara manual terdapat berbagai faktor yang menjadi kekurangan misalnya standarisasi metode, keterampilan ATLM, Waktu pengerjaan, proses sentrifugasi, dan faktor-faktor lainnya. Sehingga pemeriksaan urin secara otomatis sudah menjadi kebutuhan dalam laboratorium.

Bertolak dengan uraian hal tersebut, sehingga penelitian ini bertujuan untuk mengetahui profil pemeriksaan sedimen urin menggunakan alat Dirui Fus-100 pada pasien infeksi saluran kemih. .

\section{METODE}

\section{Desain, tempat dan waktu}

Jenis penelitian observasional dengan desain deskriptif. Penelitian dilaksanakan di RSUP Dr Wahidin Sudirohusodo tahun 2020.

\section{Jumlah dan Cara Pengambilan Sampel}

Populasi penelitian ini merupakan semua pasien yang mengalami Infeksi suspek Saluran Kemih (ISK) yang datang memeriksakan diri pada RSUP Dr Wahidin Sudirohusodo. Sampel penelitian ini adalah pasien suspek yang gejala klinis dan catatan medis sebanyak 30 orang yang diambil secara consequtive sampling 30 orang suspek ISK.

\section{Bahan dan Alat}

Bahan dan Reagensia yang digunakan reagen focus, standar solution, control negatif dan positif, reagen sheath, sampel urin suspek penderita ISK. Adapun alat diantaranya
Dirui Fus-100, tabung dan rak tabung.

\section{Langkah- Langkah Penelitian}

Pemeriksaan laboratorium ini menggunakan Sedimen Urin Metode Otomatis dengan Alat Dirui FUS-100, prosedur pengerjaannya diantaranya mulai melakukan klik worklist, memasukkan data sample, apabila sudah klik Add, memasukkan rak yang sudah berisi sample urin dalam tabung. Selanjutnya klik start untuk memulai, Selanjutnya hasil akan tampil di test result, hasil akan otomatis dilaporkan oleh alat dalam satuan LPF/LPK (low Power Field/Lapangan Pandang Kecil atau HPF/LPB (High Power Field/Lapangan Pandang Besar)

Pengolahan dan analisis data

Data yang telah didapatkan merupakan data primer hasil pemeriksaan Alat Dirui FUS-100. Data yang dilaporkan dilakukan pengolahan dengan penginputan, editing, tabulasi dan analisis. Data yang diperoleh pada dilakukan analisis data secara univariat dengan menentukan nilai proporsi dari populasi.

\section{HASIL}

Penelitian ini diperoleh deskripsi parameter yang dilakukan pemeriksaan dengan Dirui FUS-100 pada Tabel 01 menunjukkan terdapat 3 parameter sebagai indikator ditandai terjadinya ISK yaitu sel eritrosit, leukosit dan Bacteria. Hasil alat ini didapatkan bahwa jumlah sel eritrosit memiliki nilai maksimun 189 HPF hampir semua sampel mengalami peningkatan dari nilai normal (0-3). Nilai sel leukosit yang terdeteksi juga menunjukkan nilai tinggi 254 HPF dari nilai normal (0-4). Begitu juga jumlah sel bakteri yang ditemukan dalam pemeriksaan alat ini memiliki nilai tertinggi $12 \mathrm{HPF}$ (0-1) sel.

Berdasarkan Tabel 2 diperoleh sebagian besar pasien mengalami hematuria yaitu sebanyak 20 orang 
(67\%) memiliki jumlah eritrosit urine $>3$ HLP. Sedangkan pasien dengan jumlah eritrosit urine 0- 3 HLP terdapat pada 10 orang (33\%).

Tabel 3 diperoleh sebagian besar pasien mengalami leukosituria yaitu sebanyak 20 orang $(67 \%)$ memiliki jumlah eritrosit urine >4 HLP. Sedangkan pasien dengan jumlah leukosit urine 0- 4 HLP terdapat pada 10 orang $(33 \%)$.

Tabel 4 didapatkan pasien memiliki bakteri urine yaitu sebanyak 24 orang (80\%) memiliki jumlah bakteri urine 01 HLP. Sedangkan pasien dengan jumlah bakteri urine $>1$ HLP terdapat pada 6 orang $(20 \%)$.

\section{PEMBAHASAN}

Dirui Fus-100 merupakan alat pemeriksaan sedimen urine otomatis secara invitro, yang memiliki prinsip sistem pengenalan partikel berbasis gambar digital, untuk identifikasi secara teknologi buatan untuk mengklasifikasikan gambar yang terisolasi secara otomatis dari konstituen sedimen urin, dan melaporkannya secara kuantitatif. Pembacaan Hasil sedimen dengan menggunakan Urine Analyzer adalah dinyatakan dalam HPF/LPB (High Power Field/Lapangan Pandang Besar) dan LPF/LPK (low Power Field/Lapangan Pandang Kecil.

Urine Sedimen Analyzer FUS-100 menggunakan teknologi aliran datar, prinsip uji teknologi identifikasi jaringan saraf. Pergerakan injektor dapat mendorong sampel sel mengalir datar, dan cairan sedimen urin akan menjadi rata mengalir lancar dengan upaya dari selubung datar ganda. Dan lampu stroboflash menerangi komponen visual urin masing-masing 1/40 detik di tengah sel yang mengalir. Karena kecepatan cahaya stroboflash sangat cepat, (hampir 1 mikrodetik) dengan kecepatan aliran fitful untuk sampel kita bisa mendapatkan gambaran statis sedimen urine (efek stroboflash).

Dari hasil penelitian menunjukkan bahwa Dirui Fus-100 bisa memberikan hasil pemeriksaan yang reproduktifitas dari beberapa parameter. Sesuai hasil penelitian (Yuksel et al., 2013) bahwa sensitivitas Fus100 untuk eritrosit lebih tinggi, sementara sensitivitas UriSed lebih tinggi untuk menghitung leukosit.

Hasil terjadinya peningkatan sel darah merah dalam urine yang lebih banyak ditemukan pada sampel. Keadaan ini dihubungan dengan adanya kerusakan membran glomerular atau adanya trauma vaskular disepanjang traktus urogenital (Strasinger and dan Di Lorenzo, 2016). Seperti Pada hasil penelitian (Jamil, Pertiwi and Dwitya Elvira, 2018) yang melakukan pemerksaan mikroskopis sedimen urine bahwa eritrosit urine didapatkan $80 \%$ pasien memiliki jumlah eritrosit $>1 /$ LPB dan tidak sesuai dengan nilai normal eritrosit urine yang seharusnya hanya 01/LPB.

Begitu pula hasil penelitian ini didapatkan banyaknya leukosit dalam urine. Hal ini dikarenakan terjadi adanya peningkatan leukosit dalam urine. Menurut (Jamil, Pertiwi and Dwitya Elvira, 2018) berdasarkan pemeriksaan mikroskopis didapatkan Hasil penelitian didapatkan $60 \%$ pasien memiliki jumlah leukosit >5/LPB dan $40 \%$ pasien yang memiliki jumlah leukosit pada nilai normal yaitu 0- 5/LPB. Sama seperti Aprilia (2010) diperoleh 67,86\% pasien pembesaran prostat jinak mengalami leukosituria. Leukosituria dapat terjadi karena pada pembesaran prostat jinak akan menyebabkan obtruksi pada kandung kemih dan uretra yang akan menimbulkan retensi urine. Retensi urine sangat berisiko untuk menimbulkan terjadinya infeksi saluran kemih sehingga akan ditemukannya peningkatan leukosit pada urine pasien. 
Pada penelitian (Fujita et al., 2013) juga didapatkan bahwa jumlah leukosit dikaitkan dengan derajat pembesaran prostat dan gejala saluran kemih bagian bawah.

Penelitian ini diperoleh pula adanya bakteri dalam urine, hal ini menunjukkan infeksi bakteri sekitar 6 orang pasien. Bakteri kemungkinan tampak dalam bentuk kokus atau batang. Karena ukurannya yang sangat kecil harus dilakukan observasi dan pelaporannya menggunakan lapangan pandang besar. Dapat dilaporkan dalam jumlah sedikit, sedang, atau sangat banyak per lapangan pandang. Untuk memastikan kondisi signifikan dari Infeksi saluran kemih. Bekteri sebaiknya diamati bersamaan dengan peningkatan sel darah putih yang banyak. Beberapa laboratorium hanya melaporkan hasil bakteri dengan sampel segar (Strasinger and dan Di Lorenzo, 2016).

\section{KESIMPULAN}

Disimpulkan bahwa pemeriksaan sedimen Urin menggunakan Dirui FUS100 dapat mendeteksi adanya indikasi infeksi saluran kemih dengan keberadaan sel darah merah, sel darah putih dan bakteri dalam urin.

\section{SARAN}

Penggunaan alat otomatis menjadi alternatif yang baik dalam pemeriksaan urinalisa, terutama untuk Laboratorium yang menerima sampel yang banyak, meskipun pemeriksaan secara manual masih menjadi standar emas dalam pemeriksaan sedimen urin. Untuk penelitian selanjutnya agar bisa melakukan penelitian perbandingan hasil pemeriksaan Dirui FUS-100 dan mikroskopis terhadap leukosit dan bakteri.

\section{DAFTAR PUSTAKA}

Bartoletti, R. et al. (2016) Treatment of
Urinary Tract Infection and Antibiotik Stewardship. European Association of Urology.

Cameron, J. S. (2015) 'A history of urine microscopy', Clin Chem Lab Med. doi: $10.1515 / \mathrm{cclm}-2015-0479$.

Foxman, B. (2002) 'Epidemiology of Urinary Tract Infections: Incidence, morbidity, and Econimoc Costs. Department of Epidemiology, University of Michigan School of Public Health, Ann Arbor, Michigan, USA'.

Fujita, K. et al. (2013) 'White blood cell count is positively associated with benign prostatic hyperplasia', International Journal of Urology, 21(3), pp. 308-12.

Hardjoeno, H. and Fitriani. (no date) Substansi dan Cairan Tubuh. Makasar: Lembaga Penerbitan Universitas Hasanuddin.

Jamil, A. P. Al, Pertiwi, D. and Dwitya Elvira (2018) 'Gambaran Hasil Pemeriksaan Urine pada Pasien dengan Pembesaran Prostat Jinak di RSUP DR. M. Djamil Padang', Jurnal Kesehatan Andalas, 7(1).

Kausuhe, J., Pangemanan, D. H. and Onibala, F. (2017) 'Hubungan Pemasangan Kateter Urine dengan Kejadian Infeksi Saluran Kemih di RSU GMIM Pancaran Kasih Manado', Jurnal Keperawatan, 5(2).

Strasinger, S. K. and dan Di Lorenzo, $M$. S. (2016) 'Urinalisis dan Cairan Tubuh. Alih Bahasa: D. Ramadhani, N. B. Subekti', in. Jakarta.

Yuksel, H. et al. (2013) 'Comparison of Fully Automated Urine Sediment Analyzers H800-FUS100 and Labumat-Urised with Manual Microscopy', Journal of Clinical Laboratory Analysis, 27(312-316). 
Tabel 01.

Deskripsi parameter hasil pemeriksaan Dirui FUS-100 pada 30 sampel sedimen urine ISK di RS. Wahidin Sudirohusodo

\begin{tabular}{lccc}
\hline Parameter & min & max & mean \pm SD \\
\hline Sel eritrosit & 0 & 189.00 & $38.16 \pm 50.34$ \\
Sel leukosit & 0 & 254.00 & $23.33 \pm 47.56$ \\
Bakteri & 0 & 12.00 & $1.2 \pm 2.69$ \\
Kristal yang belum & 0 & 315.00 & $21.36 \pm 61.26$ \\
diklasifikasi & 0 & 219.00 & $26.80 \pm 43.23$ \\
Epitel Squamosa & 0 & 21.00 & $2.6 \pm 4.56$ \\
Sel Epitel Non Squamosa & 0 & 1.00 & $0.06 \pm .0,25$ \\
Silinder Hialin & 0 & 3.00 & $0.20 \pm .0,61$ \\
Silinder yang belum & & & \\
diklasifikasi & 0 & 2.00 & $0.20 \pm 0,61$ \\
Sel Darah Putih yang & 0 & 7.00 & $0.23 \pm 1.27$ \\
bergerombol & 0 & 280.00 & $25.83 \pm 54.3$ \\
Sel-Sel Ragi & 0 & 0 & $0 \pm 0$ \\
Sel Mukosa & & & \\
Sperma & & & \\
\hline
\end{tabular}

Tabel 02

Distribusi frekuensi subjek penelitian berdasarkan sel eritrosit urine

\begin{tabular}{lcc}
\hline \multicolumn{1}{c}{ Eritrosit } & frekuensi & \% \\
\hline $0-3 \mathrm{HPF}$ & 10 & 33 \\
$>3 \mathrm{HPF}$ & 20 & 67 \\
\hline
\end{tabular}

Tabel 03

Distribusi frekuensi subjek penelitian berdasarkan sel leukosit urine

\begin{tabular}{lcc}
\hline \multicolumn{1}{c}{ Eritrosit } & frekuensi & \% \\
\hline $0-4 \mathrm{HPF}$ & 10 & 33 \\
$>4 \mathrm{HPF}$ & 20 & 67 \\
\hline
\end{tabular}

Tabel 04

Distribusi frekuensi subjek penelitian berdasarkan sel bakteri

\begin{tabular}{lcc}
\hline \multicolumn{1}{c}{ Eritrosit } & frekuensi & \% \\
\hline $0-1 \mathrm{HPF}$ & 24 & 80 \\
$>1 \mathrm{HPF}$ & 6 & 20 \\
\hline
\end{tabular}

